\title{
Pengembangan Model Etnoparenting Indonesia pada Pengasuhan Anak
}

\author{
Yeni Rachmawati \\ Pendidikan Anak Usia Dini, Universitas Pendidikan Indonesia \\ DOI: $\underline{10.31004 / \text { obsesi.v5i2.706 }}$
}

\begin{abstract}
Abstrak
Indonesia adalah negara kepulauan terbesar di dunia yang dikenal dengan keragaman etnis dan budayanya. Dalam mengelola keragaman ini, paradigma pembangunan yang dapat memetakan persoalan dan mengembangkan berbagai program yang mengakar pada jati diri bangsa masih menjadi kebutuhan dan tantangan tersendiri. Kajian parenting lokal dilakukan salah satunya bertujuan untuk memenuhi kebutuhan tersebut. Melalui berbagai kajian parenting lokal diharapkan akan tergali berbagai khazanah kekayaan di Indonesia dalam bidang pengasuhan anak. Tujuan artikel ini adalah memaparkan rumusan model etnoparenting di Indonesia, yang memiliki 4 elemen utama yaitu nilai Ketuhanan, nilai utama jati diri manusia, kepedulian terhadap alam dan lingkungan serta sikap gotong royong dan keterlibatan masyarakat dalam pengasuhan anak. Artikel ini merupakan systematic review yang mengolah data dari berbagai hasil penelitian, jurnal dan dokumen tertulis lainnya terkait kajian lokal dalam pengasuhan anak. Dalam artikel ini akan dibahas tentang rumusan model etnoparenting, yang diawali dengan paparan dinamika perkembangan kajian lokal di Indonesia.
\end{abstract}

Keywords: model etnoparenting indonesia; kearifan lokal; pengasuhan anak

\begin{abstract}
Abstrak
Indonesia is the largest archipelago Asian country in the world. It has 16,056 islands and 1,340 ethnic groups. Until today, Indonesian still develops concepts and ideas to maintain this abundance of diversity. The orchestrating ideas of diversity are needed for mapping problems and develop various programs that are rooted in national identity. The study of ethno parenting was carried out to meet these needs. This study will explore various treasures of local wisdom in Indonesia, especially in the area of caring for children under five. Each tribe in Indonesia has its uniqueness in raising a child. The purpose of this article is to describe ethno parenting models in Indonesia. This article is a systematic review that uses various sources from some researches, journals, and documents related to childcare local studies. This article will discuss the ethnoparenting model development and the growth of local studies in Indonesia.
\end{abstract}

Keywords: model ethnoparenting Indonesia; local wisdom; parenting.

Copyright (c) 2020 Yeni Rachmawati

$\triangle$ Corresponding author :

Email Address: yeni_rachmawati@upi.edu (Jl.dr.Setiabudhi 229 Bandung)

Received 5 August 2020, Accepted 6 October 2020, Published 16 October 2020 


\section{PENDAHULUAN}

Indonesia adalah negara Asia Tenggara yang dikenal dengan negara kepulauan terbesar di dunia (the largest archipelago country in the world). Lokasinya terletak di garis khatulistiwa, antara Benua Asia dan Australia serta antara Samudera Pasifik dan Samudera Hindia (Kementrian Sekretariat Negara Republik Indonesia, 2013; Albert, Trommsdorff, Mayer, \& Schwarz, 2005). Berdasarkan data yang diperoleh dari Badan Pusat Statistik tahun 2015, populasi Indonesia secara absolut meningkat dari 237.641.326 jiwa di tahun 2010 (Badan Pusat Statistik, 2013) menjadi 255,2 juta jiwa di tahun 2015, di mana lebih dari 60 persennya merupakan penduduk usia produktif (usia 15- 64 tahun), sehingga Indonesia menempati peringkat keempat penduduk terbesar di dunia setelah China, India, dan Amerika Serikat (Kementrian Sekretariat Negara Republik Indonesia, 2013). Selain itu, Indonesia juga memiliki 16.056 Pulau (Badan Informasi Geospasial, 2017) dan 1.340 suku bangsa (Indonesia.go.id, 2020). Berdasarkan fenomena keragaman ini sangat relevan untuk mengatakan bahwa Indonesia adalah a very diverse country (Miksic, 2002).

Sebagai bangsa yang besar dan beragam, maka berbagai kajian ilmiah untuk memahami keragaman di Indonesia mulai dari agama, bahasa, budaya, etnis, dan sumber alamnya adalah hal yang prinsip dan fundamental. Para pendiri bangsa Indonesia pun telah meramu keragaman ini dalam simbol -Bhineka Tunggal Ika- yang bermakna "satu dalam keragaman". Namun, persoalan bagaimana Bhineka Tunggal Ika ini menjiwai dalam keseluruhan aspek pembangunan di Indonesia, hal itu masih menjadi tantangan yang besar. Kajian-kajian khazanah lokal dalam beberapa bidang seperti dalam pembelajaran, linguistik, mitigasi bencana, sastra, botani, terbilang masih jarang dilakukan (Ifandi, 2020; Situmorang, 2018; Setyorini, 2017; Novitasari, Agustina, Sukesti, \& Nazr, 2017; Maryani \& Yani, 2014) termasuk jarangnya kajian lokal dalam bidang pengasuhan anak (Rachmawati , 2017). Hingga hari ini, bangsa Indonesia masih membutuhkan berbagai sumbangsih pemikiran, konsep dan pengelolaan khazanah kekayaan ini. Konsep-konsep pembangunan yang dapat memetakan persoalan dan mengembangkan berbagai program yang mengakar pada jati diri bangsa Indonesia sangat dinantikan. Hal ini tiada lain adalah untuk kemajuan, kemanfaatan dan kesejahteraan yang lebih luas bagi seluruh rakyat Indonesia.

Kajian parenting lokal dilakukan dengan harapan akan tergali berbagai khazanah kekayaan budaya dalam bidang pengasuhan anak. Data yang digunakan sebagai bahan penyusunan model etnoparenting diawali oleh preliminary research pada tahun 2014 (Rachmawati, Pai, \& Chen, 2014). Saat itu peneliti melakukan kajian terkait pendidikan multi kultur di Indonesia. Selanjutnya tahun 2016 dilakukan kajian tentang pentingnya pendidikan berbasis pengembangan jati diri individu, kewilayahan, dan kebangsaan di Indonesia (Rachmawati \& Komariah, 2016). Proses selanjutnya penulis mulai melakukan riset yang lebih spesifik tahun 2017, dengan menggali indigenous parenting di suku Sunda khususnya di Kampung Naga, Jawa Barat (Rachmawati , 2017). Melalui penelitian itu di temukan data bahwa Suku Sunda di kampung Naga memiliki tradisi dan cara pandang tersendiri dalam memahami kehadiran anak (the value of children), memposisikan kedudukan ibu, dan tradisi menyambut kehadiran bayi sebagai manusia baru. Kampung Naga juga memiliki tradisi gotong royong. Semua unsur masyarakat, termasuk para Sesepuh pun ikut terlibat dalam membesarkan seorang anak. Selanjutnya pada tahun 2018 dilakukan penelitian Indigenous parenting di suku Bali (Rachmawati, Listiana, \& Rudiyanto, 2018). Ditemukan terdapat tradisi pengasuhan masyarakat Bali yang dikenal dengan upacara "daur hidup" terkait setiap perubahan dalam perkembangan hidup manusia. Tahun 2019 dilanjutkan dengan penelitian Indigenous parenting di suku Dayak, yang mengingatkan orang tua bahwa anak adalah karunia dan titipan Jubata atau Tuhan (Rachmawati \& Gustiana, 2019). Sebagai tambahan data, penulis juga membimbing tesis mahasiswa, yang mendalami payung penelitian yang sama. Diantaranya Firdayani (2019) yang meneliti tentang pengasuhan anak di Kampong Arab, Palembang, juga Anfalia, Rachmawati, \& Yulindrasari (2020) yang meneliti tentang pengasuhan dan pendidikan karakter di suku Samin. Tahun 2019 juga dilakukan Lokakarya 
etnoparenting Bersama Seameo Ceccep yang membahas pengasuhan di 10 etnis di Nusantara, yaitu Papua, Bali, NTT, Ambon, Minang, Batak, Bugis, Dayak, Sunda dan Jawa.

Berdasarkan latarbelakang diatas, maka artikel ini ditulis untuk memformulasikan rumusan pengertian dan model etnoparenting yang dikembangkan berdasarkan hasil riset dan kajian literatur yang telah dilakukan peneliti 3 tahun terakhir terkait pengasuhan anak berbasis kearifan lokal di Indonesia. Model etnoparenting yang dikembangkan merupakan intisari dan "benang merah" pengasuhan anak yang menyatukan berbagai budaya dan tradisi pengasuhan yang beragam di Indonesia.

Berbicara tentang kajian lokal di Indonesia tidaklah berjalan mulus dan sederhana. Kajian lokal mengalami fase perkembangan yang cukup dinamis. Isu kajian lokal senantiasa terkait dengan isu identitas nasional. Dalam perkembangannya Rosidi (2011) menjelaskan bahwa pada tahun 1950 ketika berbicara tentang budaya lokal, maka masyarakat akan dicurigai sebagai separatis, provinsialis, atau federalis oleh pihak pemerintah. Hal itu dapat terjadi disebabkan Indonesia baru saja merdeka dan berumur 5 tahun. Indonesia sedang membangun bentuk "persatuan" dan "identitas nasional" dalam keanekaragaman budaya yang ada. Namun, secara bertahap kondisi itu berubah dalam 20 tahun kemudian. Sekitar tahun 1970-an mulai muncul kajian-kajian tentang kearifan lokal. Banyak institusi , ilmuwan, para aktivis dan seniman yang mulai menggali kembali budaya lokal. Pada tahun 1980 sebuah istilah baru yaitu "local genius" mulai muncul di masyarakat Indonesia.

Namun, disisi lain muncul pula persoalan sebagaimana yang diungkapkan Rosidi (2011) bahwa sangat disayangkan, pada saat yang sama, warisan budaya sudah mulai habis terkikis arus modernisasi dan kebijakan pembangunan saat itu yang kurang berpihak pada budaya lokal. Daya tarik yang tinggi terhadap negara-negara maju, telah membuat para pembuat kebijakan mengabaikan kearifan lokal dalam mengembangkan nuansa pendidikan Indonesia (Alwasilah \& Chaeda, 2009; Al-Musanna, 2012). Rosidi (2011) menyebutkan salah satu masalah di Indonesia adalah pemerintah yang tidak mengatur program secara jelas untuk menjaga harta warisan budaya, bahkan cenderung mengabaikannya. Beberapa harta budaya ditinggalkan dan menjadi punah (Dewanggi, Hastuti, \& Hernawati, 2012). Sebagai contoh, orang-orang secara perlahan kehilangan kebaikan, keramahan, dan sikap gotong royong, dan beralih menjadi sikap uang lebih individualis dan kompetitif.

Kondisi tersebut terus berubah, hingga awal tahun 2000-an, pada saat isu globalisasi mulai merebak, maka isu lokal pun semakin menguat. Hal ini tidak hanya terjadi di Indonesia tetapi juga di seluruh dunia. Salah satu dampak globalisasi untuk kalangan tertentu ternyata membangunkan minat dan kecenderungan untuk melihat kembali pada identitas dan keunikan lokal. Gagasan kearifan lokal (local wisdom) mulai tumbuh dan menguat (Bolbas, Ethno-cultural education of school children in the education system of Belarus, 2018). Kecenderungan masyarakat global untuk mengembangkan "standardisasi dan keseragaman" di berbagai belahan bumi. Sebagaimana yang di ungkap oleh (Block \& Cameron, 2002) "...that globalization still is a hegemonic western, and above all an extension of American imperialism and domination, particularly in economic and culture. Di sisi lain, melahirkan respons dan semangat untuk membangun "ketidakseragaman dan keberagaman". Identitas lokal yang spesifik, unik, dan berbeda dengan yang lain menjadi hal menarik untuk dipelajari Persoalan tentang jati diri dan identitas kebangsaan ini menjadi isu yang semakin menarik terutama bagi masyarakat Indonesia yang beragam etnis. Bangsa Indonesia sebagai bangsa yang mandiri, dan telah melampoi masa 75 tahun merdeka (1945-2020) tentu sangat membutuhkan konsep identitas yang jelas dalam memposisikan dirinya di kancah dunia internasional.

Kajian kearifan lokal merupakan hal penting terutama di Indonesia yang memiliki khazanah karagaman local wisdom yang sangat kaya. Kajian tentang keragaman local wisdom diantaranya didasarkan pada hal-hal berikut:

Pertama, globalisasi. Makna globalisasi adalah memperluas pikiran kita dan untuk melihat berbagai budaya, ekonomi, politik, dan manusia. Setiap individu hidup dalam keragaman budaya, suku, geografi, serta latar belakang dan sejarah, sehingga kita tidak dapat 
menyangkal bahwa satu negara memiliki sejarah yang berbeda dengan negara yang lain. Beberapa negara telah merdeka selama ratusan tahun, sedangkan negara lain seperti Indonesia baru puluhan tahun saja atau bahkan ada pula negara lain yang masih berjuang untuk kemerdekaannya. Selain itu, satu negara mungkin hanya memiliki satu ras saja, tetapi negara lain memiliki ratusan suku dan ras. Ini hanyalah contoh sederhana untuk melihat pluralitas di dunia kita, tetapi cukup jelas untuk mengetahui keberadaan akan keberagaman. Kita akan paham, bahwa sangatlah tidak manusiawi jika ada upaya untuk menyeragamkan atau membuat standar yang sama untuk semua wilayah. Tentu pada akhirnya, wacana keragaman tidak hanya berhenti di gagasan atau simbol negara saja. Tetapi harus terejawantahkan dalam kebijakan dan tata kelola sistem masyarakatnya. Dengan menyadari dan memahami adanya keragaman dalam bermasyarakat, maka konsep standarisasi, penyeragaman yang memandang sebuah persoalan hanya dengan satu perspektif menjadi gugur dengan sendirinya. Begitu pula yang terjadi di Indonesia. Isu mengelola dan hidup dalam keragaman merupakan tugas dan misi besar bagi semua warga negara. Pendekatan model Etnoparenting dalam pengasuhan anak adalah salah satu konsep yang mencoba merealisasikan gagasan ini.

Kedua, Pengetahuan manusia tidak dapat dipisahkan dari realitas sosialnya. Menurut Vygotski dengan paham konstruktivisme nya, merupakan hal yang tidak mungkin memisahkan antara pemahaman manusia dari realitas sosial mereka (Al-Musanna, 2012). Manusia tidak bisa keluar dari realitas sosialnya. Sejak lahir hingga dewasa, seorang individu berinteraksi di alam dan lingkungannya, dengan cara dan sistem tertentu, pola pikir yang khas, serta dipengaruhi oleh paham dan keyakinannya sesuai lingkungan sosial terdekatnya. Realitas sosial sangat lekat dan memengaruhi kehidupan individu. Hal itu pula yang membentuk identitas dirinya.

Ketiga, Setiap bangsa mempunyai potensi sumber daya tersendiri. Setiap negara memiliki "sumber daya yang potensial" yang sangat mungkin tidak dimiliki oleh negara lain. Sangatlah disayangkan jika kekayaan ini tidak dikaji dan diperdalam dengan baik. Karena sumber daya lokal akan terkait dengan berbagai aspek kehidupan. Bukan hanya terkait dengan ekonomi namun juga terkait dengan bidang lain. Apa yang didapatkan dari visi kearifan lokal ini dapat dikembangkan dalam bidang pendidikan. Untuk mempersiapkan diri menghadapi tantangan globalisasi, bidang pendidikan perlu lebih otentik secara budaya. Pemanfaatan pengetahuan asli (indigenous knowledge) akan menjadi dasar dari tugas ini (Gopinathan, 2006) .

Terkait dengan proses relasi budaya dalam pengasuhan, di Indonesia, pemerintah memiliki panduan untuk mendefinisikan budaya daerah dalam Peraturan Menteri Dalam Negeri Nomor 39 Tahun 2007 Pasal 1 sebagai berikut: "Budaya daerah sebagai suatu sistem nilai yang dianut oleh komunitas/kelompok masyarakat tertentu di daerah yang diyakini akan dapat memenuhi harapan-harapan warga masyarakatnya dan di dalamnya terdapat nilai-nilai, sikap, tata cara masyarakat yang diyakini dapat memenuhi kehidupan warga masyarakatnya" (Dirjen Kesbangpol Depdagri, Permendagri, 2017; Kementrian Sekretariat Negara Republik Indonesia, 2013).

Secara umum, kearifan local adalah budaya yang masih asli, orisinal, murni, dan terkait dengan kehidupan penduduk asli di satu wilayah tertentu. Collins dictionary (2020) menyebutkan arti kata -Indigenous sebagai " originating in and characteristic of a particular region or country; native" atau arti yang lainnya sebagai "existing, growing, or produced naturally in a region or country; belonging (to) as a native" Dapat kita artikan bebas sebagai suatu keadaan yang asli/asal/pribumi dan memiliki karakteristik yang merujuk pada wilayah atau suatu bangsa tertentu, yang masih asli (pribumi). Dia exist, tumbuh, berkembang secara alami dalam wilayah dan bangsanya, dan bagian dari penduduk asli/native.

Terpeliharanya nilai-nilai utama dan penting dari suatu masyarakat lokal disebabkan oleh kekuatan koneksi, kedalaman penghormatan, dan keterikatan yang kuat pada "Ibu Pertiwi". Karakteristik Ini pada umumnya tidak dapat ditemukan pada pola pikir masyarakat 
orang barat (Hiltner, 2011). Wacana tentang budaya asli masyarakat lokal berawal dari kepercayaan bahwa setiap komunitas memiliki kepedulian untuk menjaga dan mempertahankan kelangsungan kehidupannya (Al-Musanna, 2012). Selanjutnya, budaya asli atau lokal terhubung langsung dengan harga diri individu dan rasa identitas yang kuat terkait sejarah, leluhur, dan relasi dengan tanah mereka. Al-Musanna (2012) menekankan bahwa pada umumnya masyarakat adat memiliki kearifan lokal yang mengandung nilai-nilai yang diperlukan untuk mewujudkan kehidupan yang lebih bermakna.

Al-Musanna (2012) mengatakan bahwa dalam setiap wacana adat mengandung perspektif teologis, kosmologis, dan sosiologis. Sejalan dengan isu-isu tersebut, muatan budaya lokal juga terkait dengan isu kesejatian manusia, identitas diri, keadilan sosial, nilainilai orisinal, pondasi dan keterikatan dengan tanah air dan ibu pertiwi, serta terkait erat dengan sejarah dan asal usul masyarakatnya. Isu mengenai local genius sangat penting dalam kehidupan manusia karena hal itu berbicara mengenai makna dan nilai kesejatian seorang individu.

Kajian tentang masyarakat asli pribumi, membantu kita melihat secara jujur tentang diri kita sendiri sebagai manusia. Arus global dan kehidupan modern sedikit banyak mempengaruhi individu dan cenderung menjadikan manusia lebih duniawi dan mengabaikan makna hakiki kehidupannya. Terombang-ambing dalam gaya hidup bangsa lain yang belum tentu cocok dengan kehidupannya. Dengan menjaga kemurnian nilai-nilai utama suatu budaya, secara tidak langsung berarti telah menjaga nilai-nilai dasar manusia sebagai individu.

Pendekatan terhadap isu-isu adat di Indonesia mendorong kita untuk menghargai keunikan dan perbedaan setiap individu, itu berarti kita juga akan menghormati tatanan sosial masyarakat dan negara. Indonesia adalah masyarakat yang beragam, respek terhadap keragaman dan perbedaan ini lah yang akan membangun sikap yang lebih adil dalam bermasyarakat. Sikap peduli dan menghargai keragaman lah yang akan menjadi dasar individu dalam menempatkan diri dan orang lain dalam kesetaraan yang mandiri. Serta jauh dari sikap arogansi, superiority dan menjadikan individu lain sebagai subordinat.

Lebih lanjut, isu mengenai lokal membimbing kita untuk kembali ke alam. Ini menuntun kita untuk hidup selaras dengan tanah, air, udara, serta beragam kondisi lingkungan di sekitar kita. Itu membuat kita merekonstruksi, memposisikan ulang, dan mendefinisikan kembali nilai-nilai manusia yang berkaitan dengan alam, tempat yang kita tinggali. Masyarakat pesisir tentu memiliki karakteristik yang berbeda dengan mereka yang tinggal di hutan dan perkebunan. Masyarakat di pegunungan tentu berbeda kebiasaan dengan mereka yang biasa hidup di laut. Bagaimana menjaga kelestariannya dan bagaimana hidup di dalamnya memiliki pengetahuan dan seni tersendiri. Persoalannya hari ini, masyarakat semakin tercerabut dari alamnya. Kepedulian terhadap keseimbangan dan kelestarian alam semakin terabaikan. Selain itu bumi kita telah sedemikian massif dieksploitasi hanya untuk kepentingan industri dan beberapa gelintir perusahaan raksasa. Namun dampak kerusakan alam akan kembali menimpa jadi bencana bagi penduduk setempat dan masyarakat dunia yang lebih luas.

Selain itu, isu yang tak kalah menarik dan banyak ditemukan dalam tradisi kearifan lokal adalah kekuatan hubungan dan keterpautan dengan figur Tuhan Sang Pencipta. Kesadaran akan adanya kekuasaan yang Maha Besar di luar kekuatan manusia. Dalam banyak kisah rakyat dan tradisi adat istiadat, ditemukan keyakinan mereka yang selalu terhubung dengan Tuhan. Namun, sayangnya keyakinan ini sudah mulai luntur di sebagian masyarakat modern. Sementara di negara maju dalam perkembangannya, keyakinan terhadap agama ini mulai kembali dilirik, karena ruang kosong ini ternyata telah meninggalkan persoalan tersendiri bagi masyarakat modern. Kemurnian masyarakat Indigenous menginspirasi dan membantu masyarakat modern untuk melakukan refleksi terhadap keberadaan kekuatan besar ilahiah ini. 


\section{METODOLOGI}

Artikel ini merupakan systematic review yang menjadikan hasil penelitian dan dokumen tertulis sebagai sumber data. Data utama diperoleh dari hasil penelitian penulis dalam 3 (tiga) tahun terakhir yang mengkaji pengasuhan anak di beberapa suku bangsa di Indonesia. Diantaranya pengasuhan anak di suku Sunda, Jawa, Bali, Dayak, NTT, Ambon, Minang, Batak, Bugis dan Papua. Selain itu, penulis juga menggunakan sumber referensi lainnya sebagai data penunjang penelitian. Data selanjutnya dianalisis berdasarkan proses coding, pengelompokkan dan seleksi codding serta membuat tema, dilakukan proses identifikasi hubungan, keterkaitan dan pola antar tema, disusun kategorisasi dan Tema tahap kedua, dan tahap akhir dilakukan proses integrasi, interpretasi dan membuat ringkasan. Selanjutnya dibuat pembahasan hasil analisis dalam bentuk rumusan model etnoparenting.

Rumusan model Etnoparenting dibangun dari sistem nilai dan pengasuhan anak yang bersumber pada 7 (tujuh) elemen budaya suatu tempat (Koentjaraningrat, 2009), yaitu religious system, system of knowledge, Bahasa, seni, system of life, social organization dan system of subsistence. Dari 7 (tujuh) elemen tersebut terbangun sistem nilai dalam pengasuhan anak. Sistem nilai pengasuhan tersebut diantaranya keyakinan, agama, perspektif orang tua, tata nilai, pola hidup, tradisi, adat istiadat atau kebiasaan, dan pengalaman. Hal ini sangat spesifik terkait budaya dan etnis masing-masing. Setiap etnis sangat mungkin memiliki nilai yang unik dan spesifik berbeda dengan yang lain, walau pun sangat mungkin pula memiliki kesamaan dengan etnis lain. Hal inilah yang membangun konsep dasar Etnoparenting (Gambar 1.1).

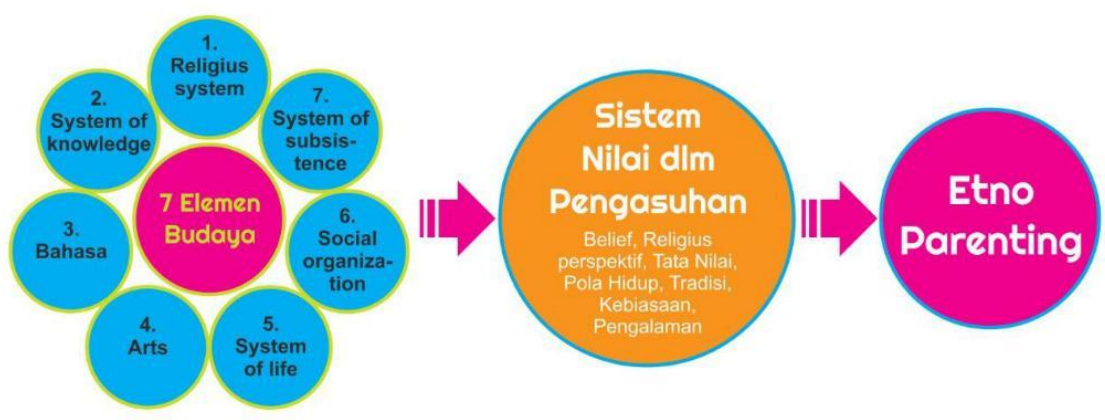

\section{Gambar 1.1. Proses Relasi Budaya dan Sistem Nilai Pengasuhan dalam Etnoparenting (diadaptasi dari Koentjaraningrat, 2009)}

Tahap selanjutnya, fokus riset di arahkan pada penggalian khazanah pengasuhan anak berbasis budaya lokal baik berupa falsafah, adat kebiasaan, keyakinan, tradisi, maupun praktik implementasi dalam membesarkan seorang anak berdasarkan akar budaya pada suatu identitas masyarakat etnis tertentu. Upaya menggali dan mengkaji indigenous parenting di berbagai suku bangsa di Indonesia menjadi fondasi dalam pembentukan model "The genuine concept of Ethno Parenting". Rumusan model Etnoparenting yang akan dikembangkan merupakan konsep pendidikan yang lahir dari orisinalitas budaya Indonesia. "The genuine concept of Ethno Parenting Indonesia" adalah sebuah visi yang diusung dalam road map penelitian penulis dalam 3 tahun terakhir (2017 sd sekarang). Di Indonesia sendiri, visi ini penting mengingat masyarakat Indonesia yang multi etnis dan beragam. keberagaman etnis dalam pengasuhan anak menjadi dasar bagi pengembangan "a typical parenting education model theory" di Indonesia.

Dalam perkembangannya, ditemukan formulasi parenting yang khas, bahwa sekalipun Indonesia sebagai negara besar yang muti etnis dan beragam serta memiliki tradisi pengasuhan yang khas di setiap etnisnya, namun memiliki hal esensial dan core value yang sama. Core value inilah yang mengikat dan menyatukan bumi nusantara. "Bhineka Tunggal 
DOI: $10.31004 /$ obsesi.v5i2.706

Ika" dalam bidang parenting menjadi nyaring terdengar. Berdasarkan formulasi inilah maka model Etnoparenting Indonesia terbangun. (Gambar 1.2).

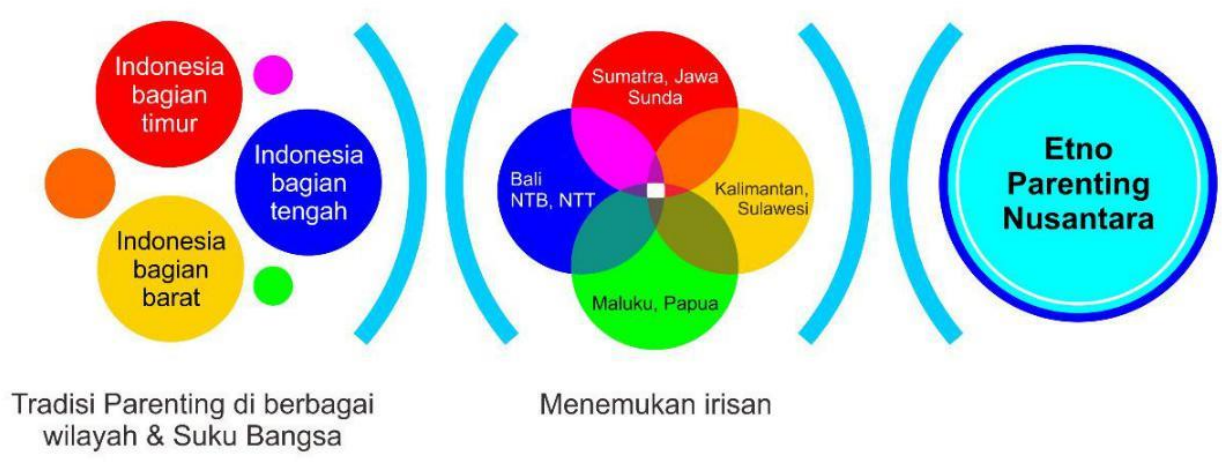

\section{Gambar 1.2 Mekanisme Pembentukan Etnoparenting Indonesia (dikembangkan penulis)}

Mekanisme pembentukan etnoparenting di bumi nusantara, diawali dengan kajiankajian parenting lokal di berbagai budaya nusantara. Yang dalam hal ini di bagi dalam tiga klister besar Indonesia bagian barat, bagian tengah dan bagian timur. Selanjutnya berbagai data parenting lokal dianalisis dan ditemukan nilai-nilai esensial antar budaya. Core value yang muncul di berbagai budaya inilah yang selanjutnya menjadi formulasi model Etnoparenting Indonesia. Core value tersebut adalah nilai Ketuhanan, nilai Jatidiri manusia, nilai pelestarian alam dan lingkungan serta gotong royong dan keterlibatan masyarakat.

\section{HASIL DAN PEMBAHASAN}

\section{Pengertian Etnoparenting}

Dalam beberapa jurnal ditemukan penggunaan istilah parental ethno theories. Istilah parental ethno theories sendiri pertama kali dicetuskan oleh pakar sosial-antropologi, Super \& Harkness, pada tahun 1986 sebagai bagian dari framework perkembangan riset mereka dalam bidang sosial-antropologi. Dalam perkembangannya, parental ethnotheories masih dianggap sebagai kajian yang samar karena bersandar pada istilah dan sifat -budayall itu sendiri yang ambigu dan dapat didefinisikan dan dipahami dalam banyak cabang dan perspektif (Zezulkova, Marketa, Stastna, \& Lucie, 2018).

Istilah Etnoparenting di Indonesia mulai diperkenalkan penulis pada akhir tahun 2019 pada sebuah Lokakarya yang diselenggarakan oleh SEAMEO CECCEP. Etnoparenting merupakan model yang berkembang sebagai lanjutan dari riset kajian parenting lokal di Indonesia (Rachmawati Y. , 2017; Rachmawati, Listiana, \& Rudiyanto, 2018; Rachmawati \& Gustiana, 2019). Sebelumnya digunakan istilah yang merujuk kearah konsep yang serupa, seperti indigenous parenting, parenting tradition, local wisdom parenting, kearifan lokal dalam pengasuhan anak, atau pun pengasuhan berbasis lokal. Ada pula penggunaan istilah pengasuhan yang langsung merujuk ke suku tertentu seperti among atau ngemong (Jawa), parenting Sunda (Sundanese Parenting), Parenting di Bali, Parenting di suku Dayak.

Kelahiran Etnoparenting dilatarbelakangi oleh kondisi bangsa Indonesia yang multi etnis. Sebagaimana yang telah dijelaskan sebelumnya, dari Sabang sampai Merauke Indonesia memiliki kurang lebih 16.056 Pulau (Badan Informasi Geospasial, 2017; Kementerian Sekretariat Negara Republik Indonesia) dan 1.340 suku bangsa (Indonesia.go.id, 2020). Setiap daerah memiliki ciri khas tersendiri, dimulai dari tataran filosophis hingga ke tataran praktis pengasuhan.

Pengertian Etnoparenting adalah aktivitas parenting yang dilandaskan pada budaya lokal atau etnis tertentu. Sebagaimana yang dikemukakan di awal, Indonesia merupakan negara multietnis dan beragam. Setiap daerah memiliki kekhasan tersendiri termasuk dalam 
hal pengasuhan anak.Jika didefinisikan, maka etnoparenting dapat diartikan sebagai: "Konsep dan praktik dalam pengasuhan anak-anak berdasarkan budaya lokal, tradisi, nilainilai, filosofi, dan kebiasaan di daerah asli pribumi dan/atau berdasarkan etnis tertentu"

Konsep dan praktik etnoparenting ini dalam pendidikan, pengasuhan, dan perawatan anak-anak berdasarkan sistem nilai yang dianut oleh kelompok masyarakat tertentu di daerah yang di dalamnya terdapat nilai-nilai, sikap tata cara masyarakat (sistem keagamaan, sistem pengetahuan, bahasa, seni, sistem kehidupan dan peralatan teknologi, organisasi sosial, dan sistem subsisten) yang diyakini dapat memenuhi kehidupan warga masyarakatnya".

Etnoparenting dapat pula dikatakan sebagai indigenous parenting atau pengasuhan anak yang dilakukan berdasarkan nilai-nilai kearifan lokal. Kearifan lokal pengasuhan ini terwejantahkan melalui keyakinan, pengetahuan dan tradisi pengasuhan anak yang dilakukan orang tua di suatu daerah atau etnis tertentu.

\section{Rumusan Model Etnoparenting Indonesia}

Sebagaimana yang telah dijelaskan sebelumnya, berdasarkan kajian parenting lokal yang dilakukan di berbagai wilayah di Indonesia, maka ditemukan garis merah yang menjadi Core Value yang menghubungkan tradisi parenting di satu etnis dengan tradisi parenting di etnis dan budaya yang lain. Core Value atau nilai utama dan esensial ini, berakar dari masyarakat dan ditemukan dari berbagai budaya di Indonesia. Formulasi ini yang membentuk Model Etnoparenting Indonesia.

Berikut ini adalah rumusan model etnoparenting yang dikembangkan oleh penulis.

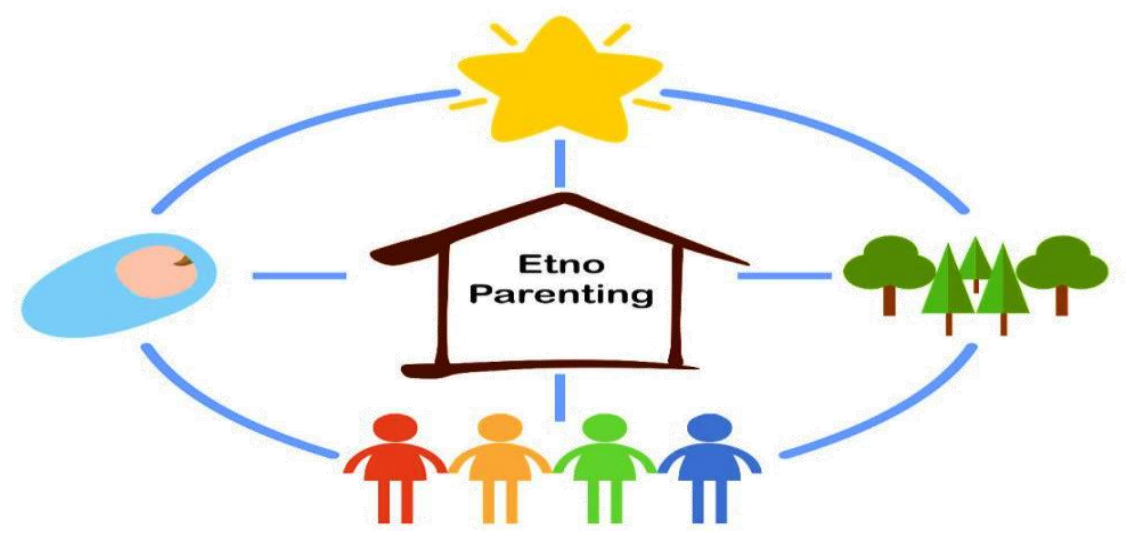

\section{Gambar 1.3 Model Etnoparenting Indonesia (dikembangkan penulis)}

Adapun Core Value yang menjadi pondasi Model Etnoparenting Indonesia, adalah Nilai Ketuhanan, Nilai Kemanusiaan, Nilai Pelestari alam dan Lingkungan, serta Nilai Gotong royong dalam masyarakatan.

\section{Nilai Ketuhanan}

Bangsa Indonesia adalah masyarakat majemuk atau plural, multi etnis, multi budaya, dan multi agama. Hampir semua agama besar dunia ada di Indonesia. Di Indonesia terdapat 6 agama besar (Islam, Kristen, katolik, Hindu, Budha, konfucius) juga terdapat aliran kepercayaan lainnya. Berdasarkan fenomena keragaman ini sangat relevan untuk mengatakan bahwa Indonesia adalah a very diverse country (Miksic, 2002).

Kadar toleransi keagamaan yang tinggi sering kali disematkan sebagai citra bangsa Indonesia (Indonesia.go.id, 2020). Masyarakat Indonesia cenderung (Burhanudin, 2017). Setiap suku bangsa di Indonesia memiliki nilai Ketuhanan yang kuat, yang masih dipegang teguh hingga hari ini (Nafsia, Yufiarti, \& Supena, 2020; Rachmawati , 2017). Tidak heran jika Sila pertama dalam Pancasila adalah Ketuhanan Yang Maha Esa. Banyak ditemukan dalam 
keyakinan dan upacara tradisi lokal yang merepresentasikan pengakuan terhadap adanya Tuhan, sebagai sumber kekuatan yang Maha Besar di luar kekuatan manusia (Rachmawati , 2017). Demikian pula dalam banyak kisah-kisah rakyat atau implementasi adat istiadat yang selalu berlandaskan pada agama, keyakinan dan kepercayaan terhadap Yang Maha Kuasa.

\section{Nilai Utama Jati Diri Manusia,}

Beberapa budaya besar Indonesia, memiliki ekspresi dan pembahasaan tersendiri tentang konsep jati diri "Manusia Paripurna". Jika dalam undang-undang Pendidikan dikenal dengan konsep "Manusia Indonesia Seutuhnya". Apa dan seperti apa, turunannya perlu dijawantahkan dengan lebih praktis. Namun sekalipun konsep ini terekspresikan secara beragam, namun pendekatan jati diri ini mendorong kita untuk menghargai keunikan dan perbedaan setiap individu. Konsep yang lahir terkait dengan konteks dan kewilayahan masing-masing. Hal ini berarti kita juga akan menghormati tatanan sosial masyarakat dan negara secara lebih luas. Indonesia adalah masyarakat yang beragam, respek terhadap keragaman dan perbedaan ini lah yang akan membangun sikap yang lebih adil dalam bermasyarakat.

\section{Nilai Pelestarian alam dan lingkungan,}

Nilai-nilai tradisi sangat menghargai dan menjaga alam dan lingkungan. Tradisi lokal membimbing kita untuk kembali ke alam. Ini menuntun kita untuk hidup selaras dengan tanah, air, udara, serta beragam kondisi lingkungan di sekitar kita. Hal ini akan membantu kita merekonstruksi, memposisikan ulang, dan mendefinisikan kembali nilai-nilai kemanusiaan yang berkaitan dengan alam dan tempat yang kita tinggali. Bagaimana masyarakat yang tinggal di pegunungan tentu berbeda dengan masyarakat yang tinggal di pesisir atau hutan. Masing-masing memiliki hibungan dan tata cara kehidupan tersendiri. Kepedualian besar masyarakat adat terhadap alam, salah satunya di tandai dengan adanya Hutan larangan. Banyak manfaat yang diperoleh masyarakat setempat atau pun masyarakat yang lebih luas dengan keberdaan hutan larangan ini. Konsep penjagaan hutan oleh masyarakat adat ini telah diadopsi oleh UNICEF karena dianggap lebih efektif dari pengelolaan negara (Setiaji, Ashari, \& Dharmawan, 2017). Konsep local wisdom terhadap alam telah menunjukkan kemampuannya untuk bertahan dalam kancah global. Beberapa Kampung adat yang memiliki Hutan larangan, akan sangat menjaga dan memberlakukan aturan ketat untuk tidak mengusik apalagi menebang pohon yang ada disana. Lebih lanjut Setiaji, Ashari, \& Dharmawan (2017) menyatakan bahwa biodiversitas yang ada di ekosistem hutan memiliki banyak potensi dan manfaat bagi peningkatan kesejahteraan masyarakat luas. Hutan memiliki stok karbon, sumber mata air, bahan pangan, obat-obatan, maupun kayu (Setiaji, Ashari, \& Dharmawan, 2017). Beberapa masyarakat adat di Indonesia yang memiliki Hutan larangan atau hutan keramat diantaranya Kampung Naga Tasikmalaya (Rachmawati , 2017). Masyarakat adat Ammatoa Bulukumba Sulawesi Selatan (Syarif, 2019), Rangkas Bitung (Royyani, 2012), Masyarakat Mollo hutan Gunung Mutis, Pulau Timor, Masyarakat Tasik Betung, Masyarakat Rano Kabupaten Donggala (Setiaji, Ashari, \& Dharmawan, 2017).

\section{Nilai Gotong Royong dan Keterlibatan Masyarakat}

Dalam berbagai budaya masyarakat asli Indonesia kita akan menemukan perilaku dan sikap gotong royong, termasuk dalam bidang pengasuhan anak. Gotong-royong merupakan urat nadi bangsa Indonesia (Dewantara A. , 2017; Irfan, 2017; Dewantara A. W., 2015; Rochmadi, 2012; Nafsia, Yufiarti, \& Supena, 2020). Lebih lanjut Dewantara A (2017) mengungkapkan bahwa gotong royong adalah filosofi hidup yang mengakar lama dalam budaya Indonesia. Gotong royong menggambarkan secara filosofis manusia dan bangsa Indonesia. Dalam gotong royong terdapat nilai-nilai kebersamaan, kerja sama demi keadilan, musyawarah untuk mufakat serta saling menghargai (Dewantara A. , 2017). Dalam analisa semantik yang dilakukan oleh Dewantara A. (2017) gotong royong bisa dimaknai sebagai: 
bekerja bersama-sama, saling bantu, dan bahu-membahu untuk mencapai hasil yang didambakan. Gotong royong diasalkan dari paham "karyo" dan "gawe" bersama yang amat khas Indonesia.

Keempat elemen ini merupakan jantung setiap parenting yang ada dalam berbagai tradisi di berbagai suku bangsa dan budaya di Indonesia.

\section{Keutamaan Model Etnoparenting Indonesia}

Implementasi Etnoparenting merupakan kebutuhan masyarakat, mengingat permasalahan stunting, gizi buruk, kematian ibu dan anak yang masih tinggi di Indonesia (Fitroh \& Oktavianingsih, 2020), sementara kekayaan alam dan lingkungan sangat kaya, termasuk di daerah terpencil. Persoalannya adalah masih kurangnya pengetahuan dan inisiasi untuk kembali pada local wisdom yang sudah dikenal di masyarakat, sedangkan proses informasi, globalisasi, dan cara hidup yang jauh dari kekayaan budaya sendiri sangat massive dan gencar menyerbu masyarakat hingga ke pelosok pedesaan. Konsep dan implementasi Etnoparenting adalah proses peremajaan dan penyegaran kembali konsep-konsep pemberdayaan masyarakat dan lingkungan yang bersumber dari masyarakat dan oleh masyarakat sendiri. Pendekatan Etnoparenting fokus pada memberdayakan lingkungan terdekat dan kekayaan lokal setempat. Masing-masing wilayah yang berada dalam lokasi geografis dan alam yang beragam memiliki khazanah tersendiri sesuai dengan kondisi lokalnya. Semangatnya adalah mengusung dan memanfaatkan apa yang kita punya di tangan hari ini, itulah yang akan diolah dan dimanfaatkan. Pada umumnya, setiap budaya memiliki local wisdom tersendiri dalam mengelola alam dan melakukan problem solving terkait permasalahan lokal.

Secara ekonomi, Etnoparenting memiliki nilai ekonomis karena mengelola alam, budaya dan lingkungan sekitarnya. Tidak dibutuhkan pembiayaan mahal karena harus membayar konsultan asing. Dalam pengembangannya tidak diperlukan proses peLatihan asing atau konsultan impor yang harus berbayar dan menghabiskan banyak anggaran pemerintah. Karena masyarakat setempat tentunya lebih memahami situasi dan kondisinya sendiri. Selain itu, Etnoparenting pun menggunakan pendekatan pengasuhan yang berakar pada kearifan lokal (local wisdom) masyarakat yang tata nilai dan tradisinya sudah dikenali oleh masyarakat setempat. Proses sosialisasi dan penyegaran Kembali, relative lebih mudah dilakukan dibandingkan dengan program dari luar negeri. Etnoparenting tidak membutuhkan program pelatihan yang bersifat asing dengan program yang teraliensi dan tidak dikenal dan tercerabut dari akar masyarakat.

Selain itu, perkembangan keilmuan hari ini, segala sesuatu yang bersifat lokal telah mendapatkan tempat dan memiliki daya tawar tersendiri di kancah persaingan global. Hal ini sejalan dengan perkembangan ilmu pengetahuan yang mengembangkan aspek lokal sebagai salah satu sumber daya. Model Etnoparenting sangat memperhatikan lokal setempat sehingga ia punya ciri khas yang tidak dimiliki oleh kelompok masyarakat lain. Sehingga ia memiliki keunikan dan daya tarik tersendiri.

Indonesia sebagai bangsa bhineka, sangat membutuhkan konsep dan praktik baik yang dapat membumikan keragaman dalam keharmonian, termasuk didalamnya dunia pendidikan dan pengasuhan anak. Dalam pengasuhan anak, keluarga menempati posisi penting dan "ujung tombak" pengasuhan, karena keluarga memiliki fungsi yang strategis dalam memberikan warna pada seorang anak (Hewi, Saleh, \& Wahyuni, 2019).

\section{SIMPULAN}

Indonesia adalah negara yang kaya akan keragaman. Setiap daerah memiliki keragaman tradisi dan budaya yang khas termasuk dalam pengasuhan anak. Pengasuhan anak setiap wilayah ini dipengaruhi oleh agama dan keyakinan masyarakatnya, falsafah kehidupan dan nilai yang dianut, kondisi geografis serta nilai kolektif dalam masyarakat. Berdasarkan data yang diperoleh dari beberapa hasil riset disusun model Etnoparenting 
Indonesia yang dikembangkan berdasarkan core values dari keragaman pengasuhan anak di berbagai wilayah Indonesia. Core values model etnoparenting Indonesia ini dibangun diatas 4 elemen utama yaitu nilai Ketuhanan, jati diri manusia, keterhubungan dengan alam serta gotong royong dan keterlibatan masyarakat dalam pengasuhan anak.

\section{UCAPAN TERIMA KASIH}

Kami mengucapkan terima kasih kepada Direktorat Jenderal Pendidikan Tinggi, Kementrian Pendidikan dan Kebudayaan Republik Indonesia yang telah memberikan dukungan untuk terlaksananya penelitian ini. Juga tak lupa kepada Direktur dan staff SEAMEO CECCEP, Ketua dan staff LPPM UPI, Keluarga besar PGPAUD UPI, para mahasiswa PAUD SPs UPI, Yayasan Al-kautsar Pelita Insani Bandung, PICTS dan all crew tim pendukung penelitian etnoparenting. Semoga Allah Swt membalas semua kebajikan dan membimbing langkah kita semua. Amin.

\section{DAFTAR PUSTAKA}

Albert, I., Trommsdorff, G., Mayer, B., \& Schwarz, B. (2005). Value of children in urbn and rural Indonesia: Socio-demographic indicators, cultural aspects, and empirical findings. In Trommsdorff, \& Gisela, The value of children in cross-cultural perspective Case studies from eight societies (pp. 171-207). Lengerich: Pabst.

Al-Musanna. (2012). Articulation of teacher education based on local wisdom to preparing culturally competence teachers. Jurnal Pendidikan dan Kebudayaan, 18(3). doi:10.24832/jpnk.v18i3.92

Alwasilah, A., \& Chaeda. (2009). Pokoknya Kualitatif Dasar-Dasar Merancang. Penelitian Kualitatif. Jakarta: PT. Dunia Pustaka Jaya.

Anfalia, R., Rachmawati, Y., \& Yulindrasari, H. (2020). Values and characters of the Samin society. International Conference on Educational Psychology and Pedagogy-" Diversity in Education"(ICEPP 2019) (pp. 220-223). Bandung: Atlantis Press. doi:https://doi.org/10.2991/assehr.k.200130.118

Badan Informasi Geospasial. (2017). Indonesia Laporkan 16.056 Pulau Bernama dan Berkoordinat ke PBB. Retrieved from https://www.big.go.id/content/berita/indonesia-daftarkan16-056-pulau-bernama-dan-berkoordinat-ke-pbb

Badan Pusat Statistik. (2013). Berita Resmi Statistik. No. 06/01/Th. XVI, 2 Januari 2013.

Block, D., \& Cameron, D. (2002). Globalization and language teaching. Psychology Press.

Bolbas, V. (2018). Ethno-cultural education of school children in the education system of Belarus. 21st Century Pedagogy, 1(1), 4-9.

Bolbas, V. (2018). Ethno-cultural education of school children in the education system of Belarus. 21st Century Pedagogy, 1(1), 4-9. doi:https:/ / doi.org/10.2478/ ped21-2018-0001

Burhanudin, M. (2017). Nilai Humanisme Religius Syiir Pesantren. Jurnal Sastra Indonesia, 6(1), $35-42$.

Collins dictionary. (2020, August 5). Indigenous. Retrieved from https://www.collinsdictionary.com/dictionary/english/indigenous

Dewanggi, M., Hastuti, D., \& Hernawati, N. (2012). Pengasuhan orang tua dan kemandirian anak usia 3-5 tahun berdasarkan gender di Kampung Adat Urug. (Caring practices and autonomy of children aged 3-5 years old based on fender at Kampung Adat Urug). Jurnal Ilmu Keluarga dan Konsumen, 5(1), 19-26.

Dewantara, A. (2017). Alangkah Hebatnya Negara Gotong Royong (Indonesia Dalam Kacamata Soekarno). Yogyakarta: PT Kanisius.

Dewantara, A. W. (2015). Pancasila dan multikulturalisme Indonesia. Studia Philosophica et Theologica, 15(2), 109-126.

Dirjen Kesbangpol Depdagri, Permendagri . (2017). Peraturan Menteri Dalam Negeri Nomor 39 Tahun 2007. Jakarta: Kementerian Dalam Negeri, 2017. 
Firdayani, T. (2019). Pengasuhan Di Kampung Arab Palembang . Bandung: Universitas Pendidikan Indonesia. doi:http:// repository.upi.edu/id/eprint/39766

Fitroh, S., \& Oktavianingsih, E. (2020). Peran parenting dalam meningkatkan literasi kesehatan ibu terhadap stunting di Bangkalan Madura. Jurnal Obsesi : Jurnal Pendidikan Anak Usia Dini, 4(2), 610-619. doi:https:/ / doi.org/10.31004/obsesi.v4i2.415

Gopinathan, S. (2006). Challenging the paradigm: Notes on developing an indigenized teacher education curriculum. Improving School, 9(3), 61-272. doi:https:/ / doi.org/10.1177/1365480206069020

Hewi, L., Saleh, M., \& Wahyuni, R. (2019). Kelekatan (attachment) anak usia dini di Suku Laut Kabupaten Wakatobi. Jurnal Obsesi : Jurnal Pendidikan Anak Usia Dini, 4(1), 406-415. doi:https:// doi.org/10.31004/obsesi.v4i1.346

Hiltner, C. (2011, April 19). Why Are Indigenous Cultures So Critically Importants to Human Survival at This Time? Retrieved from https:/ / altaifellowship.wordpress.com/2011/04/19/why-are-indigenous-culturesso-critically-important-to-human-survival-at-this-time/

Ifandi, S. (2020). Pengenalan Jenis-Jenis Tumbuhan Berguna Pekaranan Dan Kebun: Melestarikan Kearifan Lokal Masyarakat Suku Kaili Tompu Kabupaten Sigi, Sulawesi Tengah. Pena Persada.

Indonesia, K. S. (2013).

Indonesia.go.id. (2020, 3 23). Retrieved from Suku Bangsa: https:// www.indonesia.go.id/profil/suku-bangsa

Irfan, M. (2017). Metamorfosis gotong royong dalam pandangan konstruksi sosial. Prosiding Penelitian dan Pengabdian kepada Masyarakat, (pp. 1-10). doi:https:// doi.org/10.24198/jppm.v4i1.14204

Kementrian Sekretariat Negara Republik Indonesia. (2013, March 3). Geografi Indonesia. Retrieved from http://indonesia.go.id.

Koentjaraningrat. (2009). Pengantar Ilmu Antropologi. Jakarta: Rineka Cipta.

Maryani, E., \& Yani, A. (2014). Kearifan lokal Masyarakat Sunda dalam memitigasi bencana dan aplikasinya sebagai sumber pembelajaran IPS berbasis nilai. Jurnal Penelitian Pendidikan, 14(2).

Miksic, J. (2002). Indonesia Heritage. Sejarah Awal. Jakarta: Grolier International Inc.

Nafsia, A., Yufiarti, Y., \& Supena, A. (2020). Pembentukan karakter anak melalui Budaya Nalo pada anak usia dini. Jurnal Obsesi : Jurnal Pendidikan Anak Usia Dini, 4(2), 703-714. doi:https:// doi.org/10.31004/obsesi.v4i2.439

Novitasari, L., Agustina, P. A., Sukesti, R., \& Nazr. (2017). Fisika, etnosains, dan kearifan lokal dalam pembelajaran sains. SNPF (Seminar Nasional Pendidikan Fisika), (pp. 81-88).

Rachmawati , Y. (2017). An Ethnography Study on Parenting Tradition in Sundanese Culture in West Java-Indonesia. Hualien-Taiwan: National Dong Hwa University Unpublished.

Rachmawati , Y., \& Komariah, A. (2016). Promote the vision of "Jati Diri" (Core Identities) on education. The Social Sciences, 11(10), 2470-2478.

Rachmawati, \& Gustiana. (2019). Indigenous Parenting Masyarakat Dayak. Studi Kearifan Lokal Masyarakat Dayak dalam Bidang Pengasuhan Anak. Bandung: Universitas Pendidikan Indonesia.

Rachmawati, Listiana, \& Rudiyanto. (2018). Indigenous Parenting Masyarakat Bali. Studi Kearifan Lokal Masyarakat Bali dalam Bidang Pengasuhan Anak. Bandung: Universitas Pendidikan Indonesia.

Rachmawati, Y., Pai, Y. F., \& Chen, H. H. (2014). The necessity of multicultural education in Indonesia. International Journal of Education and Research, 2(10), 317-328.

Rochmadi, N. (2012). Menjadikan nilai budaya gotong-royong sebagai common identity dalam kehidupan bertetangga negara-negara ASEAN. Repository Perpustakaan Universitas Negeri Malang, 1-9. 
DOI: $10.31004 /$ obsesi.v5i2.706

Rosidi, A. (2011). Kearifan Lokal. Dalam Perspektif Budaya Sunda. Bandung: PT Kiblat Buku Utama.

Royyani, M. F. (2012). Hutan keramat dan strategi konservasi di Rangkas Bitung. J. Tek. Ling Edisi Khusus "Hari Bumi, 15-122.

Setiaji, A., Ashari, H., \& Dharmawan, M. (2017). Manajemen Hutan Lestari: Situs Keramat Alami dan Peran Masyarakat Lokal dalam Upaya Konservasi Keanekaragaman Hayati. Yogyakarta: UGM.

Setyorini, N. (2017). Kajian arkeptipal dan nilai kearifan lokal legenda di Kota Purworejo serta relevansinya sebagai bahan ajar mata kuliah kajian prosa. Literasi: Jurnal Ilmiah Pendidikan Bahasa, Sastra Indonesia dan Daerah, 7(2), 94-102.

Situmorang, R. P. (2018). Analisis potensi lokal untuk mengembangkan bahan ajar Biologi di SMA negeri 2 Wonosari. Jurnal Pendidikan Sains (JPS), 4(1), 51-57.

Syarif, E. (2019). Studi fenomenologi makna pasang ri kajang dalam pengelolaan hutan masyarakat adat Ammatoa Bulukumba Sulawesi Selatan. Malang: UM. doi:http:/ / mulok.library.um.ac.id/index3.php/79984.html

Zezulkova, Marketa, Stastna, \& Lucie. (2018). Parental ethnotheories in children's digital and media lives. The case of Romanipen. In G. Mascheroni, C. Ponte, \& A. Jorge, Digital Parenting. The Challenges for Families in the Digital Age (pp. 69-79). Göteborg: Nordicom. 